\title{
Effects of Lactation on Lipid Profile of Yankasa Ewes
}

\author{
Musa Suleman Ibrahim \\ Department of Animal Science, Nasarawa State, University Nigeria. \\ Corresponding Author: Musa Ibrahim (dribmazara@yahoo.com)
}

How to cite this article: M Ibramim. Effects of Lactation on Lipid Profile of Yankasa Ewes. Veterinary Medicine and Public Health Journal 1(2); 2020:70-71.

DOI: https://doi.org/10.31559/vmph2020.1.2.7

Received Date: 5/4/2020 Accepted Date: 28/4/2020

\begin{abstract}
The objective of the study was to evaluate the effects lactation on lipid profile of Yankasa sheep. A total of 10 ewes were used for the study, 5 lactating and 5 non lactating. The parameters evaluated included total cholesterol, triglycerides, high density lipoprotein cholesterol and low-density lipoprotein cholesterol. The results indicate significantly lower mean values of total cholesterol and triglycerides in lactating ewes compared to non-lactating ewes $(\mathrm{P}<0.05)$. The mean values of high-density lipoprotein cholesterol and low-density lipoprotein cholesterol were similar for both groups. Understanding the dynamics of lipid profile during lactation is important in providing guidelines to guarantee the metabolic needs of lactating animals and reduce the incidence of metabolic diseases.
\end{abstract}

\section{Keywords: Cholesterol, Lipoproteins, Serum, Triglycerides, Yankasa sheep}

\section{Introduction}

The critical role of lipids in body functions is well documented, they serve as hormone precursors, energy source, and metabolic fuels and act as structural components of cellular membranes (Sani et al., 2008). Significant alteration in serum levels of lipids could lead to systemic disorders in the affected animal. It has been observed that, the concentration of carbohydrates, triglycerides, high density lipoprotein cholesterol and very low-density lipoprotein cholesterol were higher at late pregnancy compared to post- partum period (Nazifi et al., 2002).

The influence of pregnancy and lactation on metabolic status of farm animals is well documented (Giuseppe et al., 2009). Thyroid hormones are reported to influence lipid metabolism by increasing lipolysis in adipose tissues and stimulating lipogenesis. Lactation is reported to result in significant changes in biochemical variables in all animals. Cholesterol synthesis is depended on energy metabolism in the liver using glucose and amino acids as key precursors. Nutritional status and fatty acid composition are important determining factors of the level of plasma cholesterol (Fair et al., 2014).

Late pregnancy in sheep has been associated with increased concentrations of total cholesterol, triglycerides and lipoproteins (Gluseppe et al., 2009). This is attributed to diminished responsiveness of tissues to insulin and increase mobilization of fatty acids from adipose tissues to meet up energy demands for fetal development. The plasma lipid profile in sheep is characterized by low triglyceride and lipoprotein concentrations (Mezur et al., 2009). Lipid profile is an important indicator of metabolic activities in lactating animals (Karapehlivan et al., 2007). Assessment of serum metabolites is therefore essential in order to understand the dynamics of metabolic disorders in farm animals.

\section{Materials and Methods Experiment site}

This study was conducted in the livestock farm of the Department of Animal Science of College Agriculture, Lafia, Nasarawa state. The location lies within latitude 08033' $\mathrm{N}$ and longitude $08033^{\prime} \mathrm{E}$ at 
an attitude of $181.53 \mathrm{~m}$ (570ft) above sea level with an annual rainfall of $1311.75 \mathrm{~cm}$

\section{Animals and management}

A total of ten (10) ewes (2-21/2 years of age) weighing $23.5-27.1 \mathrm{~kg}$ were used for the study. The animals were allowed access to grazing most of the day. Maize offal

was provided as supplementary feed and Minerals salt lick and clean drinking water provided ad libitum. All animals were given prophylactic treatment against ecto and endo parasites, by using ivermectin ( $50 \mu \mathrm{g} / \mathrm{kg}$ subcutaneously). The animals were divided into two groups (5 lactating and 5 non lactating). The lactating ewes were at 30 to 40 days postpartum.

\section{Determination of lipid profile}

Blood samples were obtained from the jugular vein for the determination of lipid profile. Triglycerides was determined using calorimetric enzymatic method with glycerophosphate oxidase, as described by Manafa et al., 2015. Standard commercial test kits manufactured by ERBA diagnostics, Mannheim Gmbh, Germany was used. Total cholesterol was determined by calorimetric enzymatic end point using reagents manufactured by Agappe diagnostics Switzerland, Gmbh. HDL Cholesterol was

measured by phosphotungstic acid method using commercial test kits produced by ERBA diagnostics, Mannheim Gmbh, Germany.

Statistical Analysis

All data obtained was analyzed using student $t$ - test.

\section{Results and Discussions}

The results indicate significantly lower mean serum values of total cholesterol and triglycerides in lactating ewes compared to non- lactating ewes $(\mathrm{P}<$ 0.05). The mean values of serum high density lipoprotein cholesterol and low-density lipoprotein cholesterol are similar for both groups.

Table (1): Effects of lactation on Serum lipid profile of Yankasa sheep (mean \pm sem)

\begin{tabular}{|l|c|c|c|c|}
\hline Parameters & $\mathrm{n}$ & $\begin{array}{l}\text { Lactating } \\
\text { ewes }\end{array}$ & $\begin{array}{l}\text { Non } \\
\text { lactating }\end{array}$ & Los \\
\hline Total cholesterol & 10 & $1.46 \pm 0.27$ & $1.90 \pm 0.32$ & $*$ \\
\hline HDL-Cholesterol & 10 & $0.80 \pm 0.20$ & $0.90 \pm 0.16$ & NS \\
\hline $\begin{array}{l}\text { LDL } \\
\text { Cholesterol }\end{array}$ & 10 & $0.40 \pm 0.12$ & $0.52 \pm 0.25$ & NS \\
\hline Triglycerides & 10 & $0.44 \pm 0.11$ & $0.74 \pm 0.15$ & $*$ \\
\hline
\end{tabular}

$*=$ Significant $(\mathrm{P}<0.05), \mathrm{HDL}=$ High Density Lipoprotein, $\mathrm{LDL}=$ Low Density Lipoprotein

Decreased serum levels of total cholesterol and triglycerides have been associated with pregnancy, postpartum period, early lactation and late lactation in ewes (Giuseppe et al., 2009). Lipid profile is useful in predicting peripartum diseases, while the contribution of triglycerides to milk synthesis is well established (Nazifi et al., 2002). Significant proportion of blood metabolites is utilized by the mammary gland during lactation. Low plasma concentrations of triglycerides and lipoprotein in sheep is associated with specie showing low participation of triglycerides in lipemia and limited hepatic synthesis of fatty acids. (Mezur et al., 2009). Similarly, lower concentrations of triglycerides and low-density lipoprotein cholesterol have been reported in lactating ewes (Antunovic et al., 2011). Variation in blood metabolites with changing physiological status justify blood metabolic profiling in assessment of nutritional status of ewes under different physiological conditions.

It can be concluded that understanding the dynamics of lipid profile and other serum metabolites during lactation is important in providing guidelines to guarantee the metabolic needs of lactating animals and reduce the incidence of metabolic diseases.

\section{References}

[1] Antunovic. Z., Novoselec. J., Sauerwen. M., Speronda. M. \& Pavic. V. Blood metabolic profile and some hormone concentration in ewes during Different physiological status. Bulgarian Journal of Agricultural Science,17 (5) (2011), 685- 695

[2] Fair. S., Doyle. D. N., Diskin. M. G., Heneessy. A. A. \& Kenny. D. A. The effects of dietary $A-3$ Polyunsaturated fatty acids supplementation of rams on semen quality and subsequent quality of liquid stored semen. Theriogenology, 81(2) (2014), 210219,

https://doi.org/10.1016/j.theriogenology.2013.09.002

[3] Giuseppe. P., Giovanni. C., Claudu. G., Fortunata. G., Sebastiano. C., Allesandro. Z. \& Pietro. P. Selected biochemical serum parameters in ewes during Pregnancy, post parturition, lactation and dry period. Animal Science Papers and Reports, 27 (4) (2009), 321- 330

[4] Karapehlivan. M., Atakisi. E., Atakisi. O., Yucart. R. \& Pancrsi. M. Blood biochemical parameters during the lactation and dry periods in Tuj Ewes. Small Ruminant Research, 73(1-3) (2007), 267- 271, https://doi.org/10.1016/j.smallrumres.2006.12.006

[5] Manafa. P. O, Aquiyi. N. C, Onyenekwe. C. C, Chukwuma. G. O, Okeke. C. O. \& Ihim. R. C. Comparative assessment of lipid profi le in pre menopausal women in Nnewi, Nigeria. European Scientifi c Journal, 1(2015), 30

[6] Mazur. A., Ozgo. M. \& Rayssiguer, Y. Altered plasma triglycerides-rich Lipoproteins and triglycerides secretions in feed restricted pregnant ewes. Vetrinarni Medicina, 54 (9) (2009), 412- 418, https://doi.org/10.17221/77/2009-vetmed

[7] Nazifi. S., Saeb. M. \& Ghavami. S. Serum lipid profile in Iranian Fat Tailed sheep in late pregnancy, parturition and during post parturition period. Journal of Veterinary Medicine, 49(1) (2002), 9- 12, https://doi.org/10.1046/j.1439-0442.2002.00405.x

[8] Sani. A., Abiodin. A. I., Isa. D.J., Joel. S. N. Nicodemus. M. U., Mohammed. B., Najume. D.G. I., Andrew. J. N. \& King. A.A. Changes in the serum Profile of lipids and cholesterol in sheep experimental model of acute African Trypanosomosis. African Journal of Biotechnology, 7 (12) (2008), 2090- 2098, https://doi.org/10.5897/ajb08.011 